\title{
PENGARUH PENGELUARAN PEMERINTAH, INVESTASI, SERTA TENAGA KERJA YANG TERSERAP TERHADAP PRODUK DOMESTIK RATIO BRUTO (PDRB) DI KOTA SAMARINDA
}

\begin{abstract}
This study was based on theory of economic development. Like that : Cobb Douglass Theory and Production function. Cobb Douglass explain that production function theory not only focus to capital, but too with teknologi and labour to increase economy growth. Production function explain too about component in system production like that input, procces and output. Input component is land, labour, capital, management, energy, information, etc which role become component from product that.

This research used secondary data published by central bureau of statistic, government expenditure, investation, labour and product domestic ratio bruto in period of 1998-2007.

This analytical results using multiple regression aided by EVIEWS software of version 4. and before analysis data, it recommended data do it stationer test it showed stationer or not stationer. Analysis result to show that government expenditure not significant to product domestic ratio bruto, investation not too significant to product domestic ratio bruto, and then absorp labour give significant point to product domestic ratio bruto. Over all if looked back to human resourced like mentality. And once again must be important "How to become good governance".
\end{abstract}

Keywords : government expenditure, investation, absorp labour and product domestic ratio bruto

\section{BAB I \\ PENDAHULUAN}

\section{A. Latar Belakang}

Anggaran Pendapatan dan Belanja Daerah (APBD) merupakan wujud pengelolaan keuangan daerah yang setiap tahunnya di tetapkan dengan peraturan daerah. Struktur anggaran pendapatan dan belanja daerah terdiri atas ( pedoman penyusunan Anggaran Pendapatan dan Belanja Daerah (APBD) tahun anggaran 2008 : 2007, 17-39):

1. Anggaran Pendapatan Daerah

2. Anggaran Belanja Daerah

3. Pembiayaan daerah

Maka dengan dasar tersebut di atas dalam upaya meningkatkan sumber pendapatan yang nantinya berpengaruh dalam meningkatkan perkembangan ekonomi di daerah yakni produk domestik ratio bruto (PDRB), pemerintah menitikberatkan pada anggaran pendapatan daerah melalui sumber penerimaan Pendapatan Asli Daerah (PAD) ( pedoman penyusunan Anggaran Pendapatan dan Belanja Daerah (APBD) tahun anggaran $2008: 2007,17)$.

Sedangkan untuk pengeluaran pemerintah yang terdiri dari belanja rutin dan belanja pembangunan di gunakan untuk membiayai proyekproyek pemerintah serta untuk membayar gaji pegawai negeri. 
Tetapi yang jadi masalah kebanyakan dari pengeluaran pemerintah tersebut adalah pengalokasian anggaran. $\mathrm{Di}$ mana pengalokasian anggaran umumnya untuk proyek-proyek mercusuar atau proyek-proyek besar. Sebagai contoh : pembangunan jembatan mahkota II. Pada kenyataannya banyak mengeluarkan anggaran yang sangat besar sebesar 353 Miliar yang kemudian karena di tabrak kapal ponton batubara mengakibatkan jembatan hancur, sehingga pemerintah harus mengeluarkan anggaran lagi, artinya kegiatan sia-sia.

secara keseluruhan dari tahun 1998 sampai dengan tahun 2007 bahwa Investasi untuk kota Samarinda setiap tahunnya mengalami peningkatan Investasi. Hal ini memberikan pengaruh yang positif bagi pertumbuhan ekonomi di kota Samarinda. Semakin baik investasi yang di tanamkan maka ukurannya akan semakin bagus pula tingkat perekonomian suatu daerah (Halim : 2006,198$)$.

Tetapi pada kenyataannya masyarakat kota Samarinda belum merasakan adanya pengaruh investasi tersebut. Seperti contoh : sering mati lampu "Byar pret" oleh PLN, dengan alasan adanya perbaikan atau perawatan mesin. Ini yang di rugikan adalah masyarakat kota Samarinda sendiri.

Dalam periode 2000-2004 perekonomian Kota Samarinda berkembang cukup pesat. Tahun 2001 mencapai 7,46 persen., tahun 2002 sebesar 10,32 persen, tahun 2003 sebesar 9,52 persen, dan tahun 2004 sebesar 9,00 persen. Sektor-sektor yang mengalami kenaikan cukup pesat, seperti sektor perdagangan hotel dan restoran, jasa, industri pengolahan, pertanian, bangunan, pertambangan dan penggalian.

Sedangkan untuk tenaga kerja yang terserap di kota Samarinda setiap tahunnya mengalami fluktuasi kadang-kadang naik maupun kadang-kadang mengalami penurunan, hal ini di sebabkan permintaan akan tenaga kerja terbatas sedangkan tenaga kerja yang tersedia sangat banyak, sehingga tenaga kerja yang terserap mengalami penurunan karena dunia usaha setiap harinya membutuhkan kemampuan (skill) yang baik dan siap bersaing.

Berdasarkan uraian di atas, maka penulis mencoba untuk mengetahui dan mengulas mengenai seberapa pengaruh pengeluaran pemerintah, investasi, serta tenaga kerja yang terserap akan mempengaruhi produk domestik ratio bruto (PDRB) di kota Samarinda, karena semakin baik PDRB suatu daerah yang di ukur melalui pertumbuhan ekonomi maka akan semakin baik pula kesejahteraan masyarakat suatu daerah khususnya kota Samarinda. Maka penulis tertarik melakukan penelitian dengan mengemukakan judul :

“PENGARUH PENGELUARAN PEMERINTAH, INVESTASI, SERTA TENAGA KERJA YANG TERSERAP TERHADAP PRODUK DOMESTIK RATIO BRUTO (PDRB) DI KOTA SAMARINDA" 


\section{B. Rumusan Masalah}

Sebagaimana yang telah dikemukakan pada latar belakang di atas maka penulis mencoba mengemukakan permasalahan, yaitu :

1. Apakah pengeluaran pemerintah berpengaruh secara signifikan terhadap produk domestik ratio bruto (PDRB) kota Samarinda?

2. Apakah investasi berpengaruh secara signifikan terhadap produk domestik ratio bruto (PDRB) kota Samarinda ?

3. Apakah tenaga kerja yang terserap berpengaruh secara signifikan terhadap produk domestik ratio bruto (PDRB) kota Samarinda ?

4. Apakah Pengeluaran pemerintah, Investasi, serta Tenaga kerja yang terserap secara bersama-sama (Simultaneous) berpengaruh secara signifikan terhadap produk domestik ratio bruto (PDRB) kota Samarinda?

5. Manakah di antara variabel-variabel tersebut yaitu Pengeluaran pemerintah, Investasi, serta Tenaga kerja yang terserap yang mempunyai pengaruh dominan terhadap produk domestik ratio bruto (PDRB) kota Samarinda?

\section{Tujuan dan Kegunaan Penelitian}

Adapun tujuan yang ingin di capai dalam penulisan ini adalah :

1. Untuk mengetahui dan menganalisis pengaruh pengeluaran pemerintah terhadap produk domestik ratio bruto (PDRB) kota Samarinda.

2. Untuk mengetahui dan menganalisis pengaruh Investasi terhadap produk domestik ratio bruto (PDRB) kota Samarinda.

3. Untuk mengetahui dan menganalisis pengaruh tenaga kerja yang terserap (labour force) terhadap produk domestik ratio bruto (PDRB) kota Samarinda.

4. Untuk mengetahui dan menganalisis pengaruh pengeluaran pemerintah, investasi, serta tenaga kerja yang terserap secara bersama-sama (Simultaneous) terhadap produk domestik ratio bruto (PDRB) kota Samarinda.

5. Untuk mengetahui dan menganalisis pengaruh yang dominanManakah yaitu Pengeluaran pemerintah, Investasi, serta Tenaga kerja yang terserap terhadap produk domestik ratio bruto (PDRB) kota Samarinda.

Sedangkan kegunaan penulisan penelitian adalah sebagai :

Bahan informasi bagi yang memerlukan khususnya bagi Pemerintah kota Samarinda agar dapat meningkatkan perkembangan / pertumbuhan ekonomi (PDRB) melalui pengeluaran pemerintah, Investasi, serta tenaga kerja yang terserap

\section{BAB II \\ DASAR TEORI}

A. Teori Pertumbuhan Ekonomi

1) Teori Klasik 
Klasik, menganalisis perekonomian sebelum tahun 1870, klasik mengemukakan : bahwa peranan modal penting artinya bagi pembangunan ekonomi. Penggunaan modal tersebut di tekankan untuk meningkatkan penawaran setinggi-tingginya, penawaran yang tinggi akan di ikuti oleh permintaan yang tinggi pula (supply creates its own demand). Tetapi kenyataannya tidak demikian, karena penawaran yang tinggi tidak di ikuti oleh permintaan yang tinggi pula.

Akibatnya, timbul :

a. Over produksi

b. Pengangguran

c. Deflasi

Asumsi klasik :

a. Perekonomian dalam keadaan full employment

b. Perekonomian dalam dua sektor (konsumen, produsen)

c. Tidak ada campur tangan pemerintah

d. Pembangunan ekonomi tergantung pada mekanisme pasar

Tokoh-tokoh klasik :

a. David Ricardo

b. Adam Smith

c. John Stuart Mill

d. Robert Malthus

David Ricardo mengatakan bahwa, adanya keterbatasan dalam tingkat kesuburan tanah menurut pendapat, walaupun produksi di tingkatkan dengan tanah yang tetap, maka akan terjadi "The Law Of Diminishing Return". Bisa di atasi dengan adanya teknologi, melalui ekstensifikasi, intensifikasi.

Asumsi Ricardo

a. Tanah terbatas

b. Modal tetap

c. Tidak ada teknologi

Stationary State : Suatu titik di dalam penambahan produksi akan mengalami penurunan atau keadaan ekonomi tidak berkembang sama sekali.

Adam Smith, teorinya "LEISSEZ FAIRE" dengan asumsi :

a. Suatu kebijaksanaan yang memberikan kebebasan sepenuhnya kepada para pelaku ekonomi untuk melakukan kegiatan ekonomi.

b. Meminimalkan campur tangan pemerintah

Adam Smith tidak menyadari adanya kenaikan hasil lebih yang semakin berkurang. Adam Smith mengemukakan, bahwa perkembangan penduduk akan mendorong pembangunan ekonomi karena akan memperluas pasar.

John Stuart Mill

Menganalisis mengenai peranan faktor-faktor non ekonomi dalam menciptakan pembangunan ekonomi. Misalnya, kebiasaan berpikir, pendidikan, adat istiadat, corak institusi dalam masyarakat. 
Beliau berpendapat, bahwa pertambahan penduduk yang terus menerus dengan luas tanah terbatas di dalam pembanunan akan menyebabkan banyak kegiatan-hukum kenaikan hasil yang semakin berkurang.

Agar pembangunan dapat tercipta, perlu adanya golongan masyarakat yang dapat menciptakan pembahuruan-pembaharuan da pentingnya peranan pendidikan dalam melaksanakan pembangunan ekonomi sebab :

a. Mempertinggi pengetahuan teknik baru

b. Mempertinggi pengetahuan umum masyarakat

Robert Malthus, mengemukakan bahwa penduduk akan mempengaruhi tingkat pertumbuhan ekonomi di mana pertambahan penduduk meningkat secara deret ukur sedangkan pertambahan bahan makanan berjalan secar deret hitung. Penentang Malthus, Double Day \& Spencer, Malthus tidak berpikir tentang teknologi.

\section{2) Teori Keynes (1937)}

Teorinya bertitik tolak dari teori klasik yang gagal terutama dalam sektor pengangguran. Menurut Keynes, pentingnya peranan modal dalam pertumbuhan perekonomian di mana penggunaan modal itu di tekankan kepada permintaan yang tinggi itu di harapkan dapat di ikuti oleh penawaran yang tinggi pula. Ternyata tidak berhasil sehingga menimbulkan, inflasi, depresi.

Asumsi Keynes :

a. Perekonomian bisa full employment \& tidak full employment

b. Perekonomian berada dalam 3 sektor (konsumen, produsen, pemerintah)

c. Adanya campur tangan pemerintah

d. Perekonomian di analisa dalam jangka pendek

\section{3) Teori Neo Klasik}

Neo Klasik, teorinya berdasarkan kepada teori klasik yang menitikberatkan pada kegiatan masyarakat dalam jangka pendek, dan sedikit sekali perhatiannya kepada masalah pertumbuhan ekonomi. Kegiatan masyarakat dalam jangka pendek adalah, kegiatan yang berlandaskan kepada mekanisme pasar.

Warisan dari Adam Smith bahwa, mekanisme pasar akan menciptakan perkembangan ekonomi walaupun berjalan secara perlahan tetapi selau berjalan secara perlahan tetapi berjalan dengan lancar dan teratur.

Tokoh-tokoh Neo Klasik 
1. Leon Walras

2. Alfred Marshal

3. Knut Wicksel

4. Cobb Douglas

Asumsi Neo Klasik :

1. Perekonomian berfungsi secara efisien akibat mekanisme pasar

2. Pembangunan ekonomi berjalan secara perlahan dan akan berjalan dengan lancar dan teratur.

4) Cobb Douglas

Mengemukakan tentang teori fungsi produksi yang menitikberatkan tidak hanya kepada modal saja, tetapi juga kepada teknologi dan tenaga kerja dalam menaikkan laju pertumbuhan ekonomi.

Fungsi produksi : $Y_{t}=T_{t} \cdot K_{t} . L_{t}$ Keterangan :

$$
\begin{array}{ll}
\mathrm{Y}_{\mathrm{t}} & =\text { tingkat produksi tahun } \mathrm{t} \\
\mathrm{T}_{\mathrm{t}} & =\text { tingkat teknologi pada tahun } \mathrm{t} \\
\mathrm{K}_{\mathrm{t}} & =\text { jumlah stok alat modal pada tahun } \mathrm{t} \\
\mathrm{L}_{\mathrm{t}} & =\text { jumlah tenaga kerja pada tahun } \mathrm{t}
\end{array}
$$

\section{B. Sejarah Pertumbuhan Ekonomi}

Pertumbuhan ekonomi tergantung pada modal, tenaga kerja dan teknologi, ada tiga komponen dalam pertumbuhan ekonomi dari setiap bangsa.

Ketiganya adalah :

1. Akumulasi modal

2. Pertumbuhan penduduk

3. Kemajuan teknologi

\section{Akumulasi modal}

Akumulasi modal terjadi apabila sebagian dari pendapatan di tabung dan di investasikan kembali dengan tujuan memperbesar output dan pendapatan di kemudian hari.

Investasi dalam pembinaan sumber daya manusia juga dapat meningkatkan kualitas modal manusia, sehingga pada akhirnya akan membawa dampak positif yang sama terhadap angka produksi, bahkan akan lebih besar lagi mengingat terus bertambahnya jumlah manusia.

\section{Pertumbuhan penduduk dan angkatan kerja}

Pertumbuhan penduduk dan pertumbuhan angkatan kerja di anggap sebagai salah satu faktor positif yang memacu pertumbuhan ekonomi.

Jumlah tenaga kerja yang lebih besar berarti akan menambah jumlah tenaga produktif, sedangkan pertumbuhan penduduk yang lebih besar berarti ukuran pasar domestiknya lebih besar.

Meskipun demikian, kita masih mempertanyakan apakah begitu cepatnya pertumbuhan penawaran angkatan kerja di negara-negara berkembang (sehingga banyak di antara mereka yang mengalami 
kelebihan tenaga kerja) benar-benar akan memberikan dampak positif, atau justru negatif, terhadap pembangunan ekonominya.

\section{Kemajuan teknologi}

Kemajuan teknologi terjadi karena di temukan cara baru atau perbaikan atas cara-cara lama dalam menangani pekerjaan-pekerjaan tradisional.

Four Wheels, terdapat empat komponen dalam pertumbuhan ekonomi, yaitu :

1. Sumber daya alam

2. Sumber daya manusia

3. Capital

4. Teknologi

\section{Peranan Penduduk di dalam Pembangunan}

Peranan tenaga manusia di tentukan oleh jumlah dan mutu daripada tenaga kerja, di Indonesia jumlah tenaga kerja besar tetapi masalah mutu masih menjadi persoalan, di negara berkembang adalah bagaimana menyalurkan kelebihan tenaga kerja yang sekarang bekerja tidak produktif.

Peranan tenaga kerja dalam pembangunan harus di lihat dari segi penduduk, di negara maju jumlah penduduk di pandang sebagai pencegah stagnasi.

Di negara berkembang jumlah penduduk merupakan bahaya dan dapat mengakibatkan stagnasi.

Persoalan di Indonesia, adalah :

1. Penyebaran penduduk yang tidak merata

2. Kesuburan tanah tidak merata

Pulau Jawa tingkat kesuburannya tinggi, penduduk padat serta dapat menghasilkan bahan makanan surplus sehingga jumlah penduduk di pulau Jawa berlipat ganda. Pemindahan penduduk di dalam negeri di pandang menguntungkan (transmigrasi) bagi pembangunan ekonomi.

\section{Pengeluaran pemerintah}

Belanja / pengeluaran pemerintah adalah pengeluaran yang di keluarkan oleh pemerintah yang ditujukan untuk pembiayaan proses pembangunan sebagai kegiatan pemerintah dalam meningkatkan kesejahteraan masyarakat ( Mardiasmo, 2002 : 185 ).

Undang-undang otonomi daerah nomor 32 tahun 2004 bahwa yang di maksud dengan belanja daerah adalah semua pengurang nilai kekayaan bersih dalam periode tahun anggaran yang bersangkutan atau uang yang keluar dari kas daerah (Anonim, 2004:4). 
Pengeluaran pembangunan di tujukan bagi peningkatan sarana dan prasarana di pelbagai sektor pembangunan. Sektor-sektor tersebut adalah sebagai berikut (Bappeda tingkat I Kaltim, 2002 : 1-20) :

1. Industri

2. Pertanian dan kehutanan

3. Sumber daya air dan irigasi

4. Tenaga kerja

5. Perdagangan, pengembangan usaha daerah, keuangan daerah dan koperasi

6. Transportasi

7. Pertambangan dan energi

8. Pertambangan dan telekomunikasi daerah

9. Pembangunan daerah dan pemukiman

10. Lingkungan hidup dan tata ruang

11. Pendidikan, kebudayaan nasional, kepercayaan terhadap Tuhan Yang Maha Esa, pemuda dan olah raga

12. Kependudukan dan keluarga berencana

13. Kesehatan, kesejahteraan sosial, peranan wanita, anak dan remaja

14. Perumahan dan pemukiman

15. Agama

16. Ilmu pengetahuan dan teknologi

17. Hukum

18. Aparatur pemerintah dan pengawasan

19. Politik, penerangan, komunikasi dan media massa

20. Keamanan dan ketertiban hukum

\section{Angkatan Kerja}

Secara umum pengukuran ketenagakerjaan dapat didekati dengan dua cara, yakni gainful worker approach dan labour force approach. Dalam gainful worker approach seseorang dalam batas umur tertentu akan di tanya : "kegiatan apa yang biasa ia lakukan dalam suatu kurun waktu tertentu". Konsep ini kurang dapat memberikan gambaran statistik yang tepat antara mereka yang bekerja dan sedang mencari pekerjaan. Konsep ini cenderung menghasilkan angka pengangguran terbuka relatif kecil.

Pendekatan lain yang paling banyak digunakan adalah labour force approach. Dalam pendekatan ini seluruh penduduk dalam kelompok umur tertentu dan dalam kurun waktu tertentu pula dikelompokkan menjadi dua kelompok, yakni mereka yang termasuk dalam kategori angkatan kerja (labour force) dan bukan angkatan kerja.

Angkatan kerja (labour force) menurut Djojohadikusumo di definisikan sebagai bagian dari jumlah penduduk yang mempunyai pekerjaan atau yang sedang mencari kesempatan untuk melakukan pekerjaan yang produktif. Bisa juga di sebut sumber daya manusia (human resources). 
Dari bagan di atas terlihat bahwa angkatan kerja merupakan bagian dari penduduk yang termasuk ke dalam usia kerja. Usia Kerja adalah suatu tingkat umur seseorang yang diharapkan sudah dapat bekerja dan menghasilkan pendapatannya sendiri. Usia kerja ini berkisar antara 14 sampai 55 tahun. Selain penduduk dalam usia kerja, ada juga penduduk di luar usia kerja, yaitu di bawah usia kerja dan di atas usia kerja. Penduduk yang dimaksud yaitu anak-anak usia sekolah dasar dan yang sudah pensiun atau berusia lanjut (Wikipedia : 2007).

Di Indonesia yang di maksud dengan angkatan kerja adalah penduduk yang berumur 10 tahun ke atas yang secara aktif melakukan kegiatan ekonomis. Angkatan kerja terdiri dari penduduk yang bekerja, mempunyai pekerjaan tetap tetapi sementara tidak bekerja, dan tidak mempunyai pekerjaan sama sekali tetapi mencari pekerjaan secara aktif. Mereka yang berumur 10 tahun atau tidak bekerja atau tidak mencari pekerjaan karena sekolah, mengurus rumah tangga, pensiun, atau secara fisik dan mental tidak memungkinkan untuk bekerja tidak dimasukkan dalam angkatan kerja.

Pembagian angkatan kerja menurut sektor terdiri atas :

1. Sektor A (pertanian, perburuhan, kehutanan dan perikanan)

2. Sektor $M$ (pertambangan, manufaktur, bangunan listrik dan air, pengangkutan, perhubungan, dan gas).

3. Sektor S (perdagangan, rumah makan, hotel, keuangan, asuransi, jasa-jasa kemasyarakatan, sosial dan pribadi).

Bagian lain dari penduduk dalam usia kerja adalah bukan angkatan kerja. Yang termasuk di dalamnya adalah para remaja yang sudah masuk usia kerja tetapi belum bekerja atau belum mencari perkerjaan karena masih sekolah. Ibu rumah tangga pun termasuk ke dalam kelompok bukan angkatan kerja (Wikipedia : 2007).

Penduduk dalam usia kerja yang termasuk angkatan kerja, di kelompokkan menjadi tenaga kerja (bekerja) dan bukan tenaga kerja (mencari kerja atau menganggur).

Tenaga Kerja (man power) adalah bagian dari angkatan kerja yang berfungsi dan ikut serta dalam proses produksi serta menghasilkan barang atau jasa (Wikipedia : 2007).

\section{F. Teori Investasi}

Teori-teori tentang investasi yang di kemukakan oleh para pakar ekonomi di antaranya adalah teori Keynes (teori multiplier) yang di kemukakan oleh John Maynard Keynes (1883-1946) yaitu bahwa untuk mempengaruhi jalannya perekonomian, pemerintah dapat memperbesar anggaran pengeluaran saat perekonomian mengalami kelesuan sehingga lapangan pekerjaan meningkat dan akhirnya pendapatan riil masyarakat juga akan mengalami peningkatan. Perubahan yang di akibatkan oeleh pengeluaran pemerintah akan berpengaruh pada besarnya pendapatan nasional yang selanjutnya akan menimbulkan perubahan pada golongan 
pengeluaran tertentu dan pada akhirnya pendapatan nasional akan bertambah, yang di sebut sebagai processing multiplier.

Terjadinya multiplier effect akan menyebabkan terjadinya perubahan ekonomi ke arah yang lebih dinamis, yaitu terciptanya lapangan pekerjaan yang di sebabkan oleh tingginya pendapatan masyarakat. Hal tersebut memberi pengaruh pada peningkatan kebutuhan masyarakat dan di butuhkan sumber-sumber produksi untuk memuaskan kebutuhan tersebut. Secara otomatis di butuhkan pula sumber daya manusia untuk mengolahnya.

Investasi mempunyai peran penting dalam perekonomian suatu negara. Alasannya yaitu pertama, investasi mampu menciptakan pendapatan dan kedua investasi dapat memperbesar kapasitas produksi perekonomian dengan cara meningkatkan stock modal. Pendapat ini sejalan dengan yang di kemukakan oleh Harrod Domar bahwa investasi tidak hanya mempengaruhi permintaan melalui multiplier effect, tetapi juga mempengaruhi penawaran melalui pengaruhnya terhadap peningkatan kapasitas produksi.

Penanaman investasi sering di lakukan melalui Penanaman Modal Asing dan Penanaman Modal Dalam Negeri. Beberapa pengertian investasi menurut beberapa ahli ekonomi:

Frank J. Fabozzi (1995: 1) manajemen investasi adalah proses pengelolaan uang.

Sukimo (1994:76) investasi adalah " Penanaman modal oleh para pengusaha yang ditentukan oleh dua faktor, yaitu efisiensi modal dan tingkat bunga".

Winardi (1988:98) juga berpendapat bahwa " Investasi adalah pengeluaran untuk barang-barang yang tidak dikonsumsi sekarang melainkan menambah jumlah barang-barang atau alat-alat produksi".

Sedangkan Herbert E. Daugall (1996:1) berpendapat tentang investasi bahwa:

Investment in the commitment of funds for the purpose of deriving future income in from of interest, rent, or retirement benefits, or appreciation in the value of principal." (Investasi adalah kewajiban untuk memberikan dan adegan maksud mendapatkan di masa depan, dalam bentuk bunga, deviden, sewa atau membawa manfaat, atau penghargaan dalam nilai pokok".

Investasi merupakan komponen pengeluaran yang cukup besar dan akan berubah-ubah dan perubahan besar dalam investasi akan sangat berpengaruh terhadap permintaan agregat dan akhirnya akan berakhir pada output dan kesempatan kerja sehingga akan mengakibatkan perbaikan pada pendapatan. Bagi kalangan investor mengadakan investasi dengan harapan bahwa pembangunan pabrik baru atau membeli mesin-mesin baru akan mendatangkan keuntungan, yaitu peningkatan hasil penjualan yang melebihi biaya-biaya investasi itu sendiri. 
Winardi (1988:98) menyatakan sebagai berikut perusahaanperusahaan mengadakan investasi agar memperoleh keuntungan barangbarang modal yang berumur lebih dan satu tahun maka keputusan untuk investasi tergantung pada:

1. Tingkat permintaan atas output yang dihasilkan investasi baru.

2. Tingkat suku bunga dan pajak yang mempengaruhi

3. Ekspolitasi dan perkiraan kalangan usahawan atas situasi ekonomi di masa yang akan datang".

Sukimo (1994:106) investasi dapat di artikan "sebagai pengeluaran/ pembelanjaan penanam modal atau perusahaan membeli barang-barang dan perlengkapan-perlengkapan produksi untuk menambah kemampuan produksi barang-barang dan jasa-jasa yang tersedia dalam perekonomian".

Pertambahan jumlah barang mi memungkinkan perekonomian tersebut menghasilkan lebih banyak barang dan jasa di masa yang akan datang.

\section{G. Teori Produksi}

Komponen dalam sistem produksi adalah input, proses dan output. Komponen input meliputi : tanah, tenaga kerja, modal (capita), manajemen, energi, informasi, dan sebagainya yang ikut berperan menjadi komponen atau bahan baku dari suatu produk.

\section{Faktor Produksi (Input) dalam Sistem Produksi}

Jenis faktor produksi secara teoritis di bagi menjadi empat, yaitu : lahan, tenaga kerja, modal dan manajemen.. faktor produksi lahan dan tenaga kerja sering di sebut dengan input utama (mother is input). Sedangkan modal dan manajemen adalah hasil modifikasi dari input utama dan sering di katakan sebagai input kedua (father is input).

Faktor produksi tenaga kerja (labor) merupakan faktor produksi yang penting untuk di perhatikan dalam proses produksi dalam jumlah yang cukup bukan saja dilihat dari tersedianya tenaga keja tetapi juga kualitas dan macam tenaga kerja. Beberapa hal yang perlu di perhatikan berkaitan dengan tenaga kerja adalah :

a. Ketersediaan tenaga kerja, ketersediannya harus cukup memadai. Banyaknya tenaga kerja yang di perlukan hendaknya di sesuaikan denga kebutuhan dalam jumlah optimal. Ketersediaan ini berhubungan dengan kualitas tenaga kerja, jenis kelamin, tingkat upah, dan sebagainya.

b. Kualitas tenaga kerja, skill harus menjadi pertimbangan yang tidak boleh diremehkan.

c. Jenis kelamin akan menentukan jenis pekerjaan.

d. Upah tenaga kerja perempuan dan laki-laki tentu berbeda.

\section{Output (produksi)}

\section{A. Produksi}


Hasil akhir dari suatu proses produksi dalam memanfaatkan input adalah produk atau output. Perbedaan atau variasi produksi dari masingmasing sektor berbeda karena perbedaab kualitas. Karena kualitas input yang baik akan menghasilkan produksi yang baik pula, begitu pula sebaliknya.

\section{H. Produk Domestik Regional Bruto (PDRB)}

Konsep pendapatan nasional pertama kali di cetuskan oleh Sir William Petty dari Inggris yang berusaha menaksir pendapatan nasional

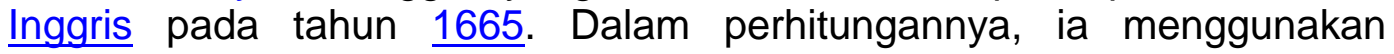
anggapan bahwa pendapatan nasional merupakan penjumlahan biaya hidup (konsumsi) selama setahun. Namun, pendapat tersebut tidak disepakati oleh para ahli ekonomi modern, sebab menurut pandangan ilmu ekonomi modern, konsumsi bukanlah satu-satunya unsur dalam perhitungan pendapatan nasional. Menurut mereka, alat utama sebagai pengukur kegiatan perekonomian adalah Produk Nasional Bruto (Gross National Product, GNP), yaitu seluruh jumlah barang dan jasa yang dihasilkan tiap tahun oleh negara yang bersangkutan diukur menurut harga pasar.

\section{BAB IV ANALISIS DAN PEMBAHASAN}

\section{A. Analisis}

Menganalisis pengaruh pengeluaran pemerintah, investasi, serta tenaga kerja yang terserap terhadap produk domestik ratio bruto (pdrb) di kota Samarinda maka dalam penelitian ini menggunakan alat analisis sebagai berikut :

1. Uji Stationeritas

2. Regresi berganda (multiple regression)

3. Uji asumsi klasik

\section{Uji Stationeritas}

Sebelum menganalisis data, maka perlu di ketahui apakah datadata seperti produk domestik ratio bruto (PDRB), pengeluaran pemerintah, investasi, serta tenaga kerja yang terserap datanya bersifat stationer atau tidak. Karena apabila data tidak stationer maka bila di regresikan akan mudah menyebabkan regresi lancung. Untuk melihat apakah data stationer atau tidak stationer dapat di lakukan dengan beberapa cara :

1. Metode grafik

2. Metode akar unit

Melakukan uji stationer untuk data produk domestik ratio bruto melalui metode grafik : 


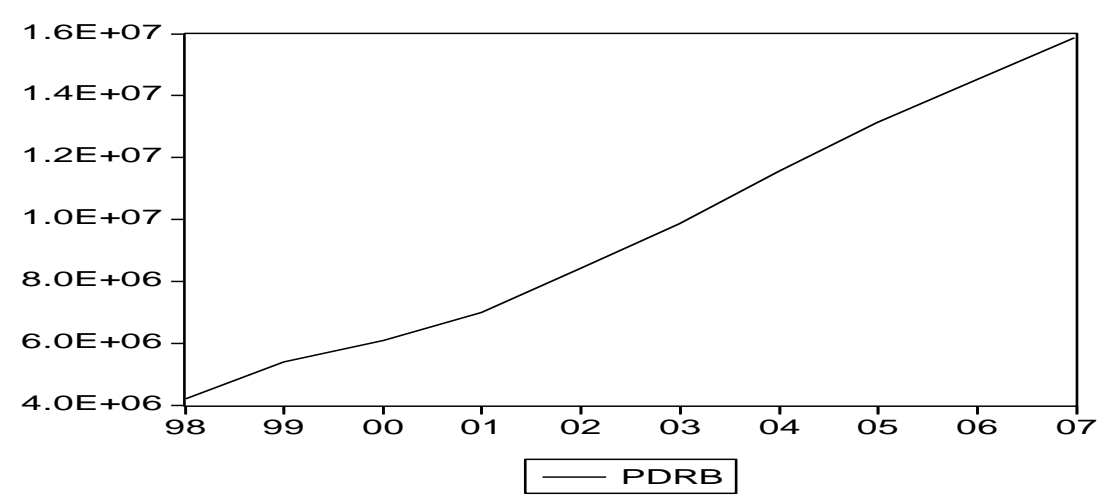

Gambar 20. PDRB melalui metode grafik

Melakukan uji stationer untuk data pengeluaran pemerintah melalui metode grafik :

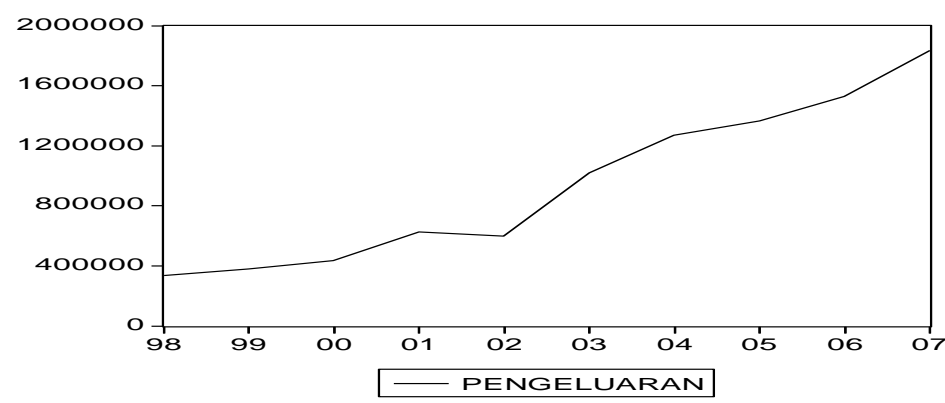

\section{Gambar 21. Pengeluaran pemerintah melalui metode grafik}

Melakukan uji stationer untuk data investasi melalui metode grafik :

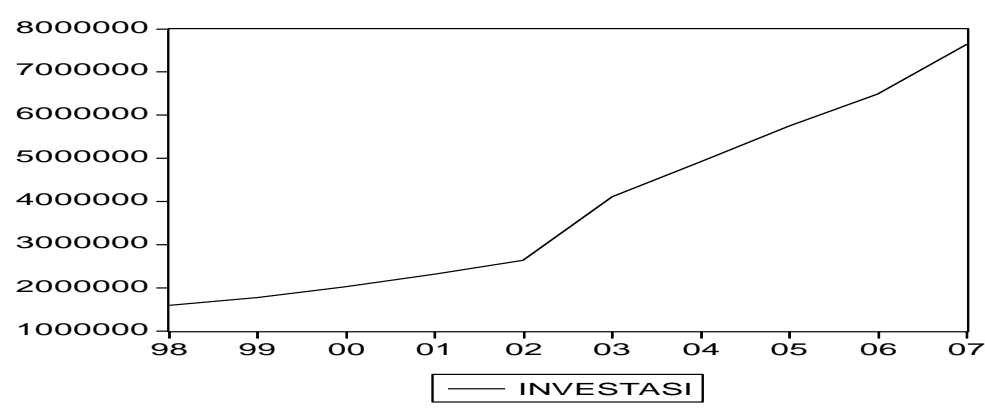

Gambar 22. Investasi melalui metode grafik

Melakukan uji stationer untuk data tenaga kerja yang terserap melalui metode grafik : 


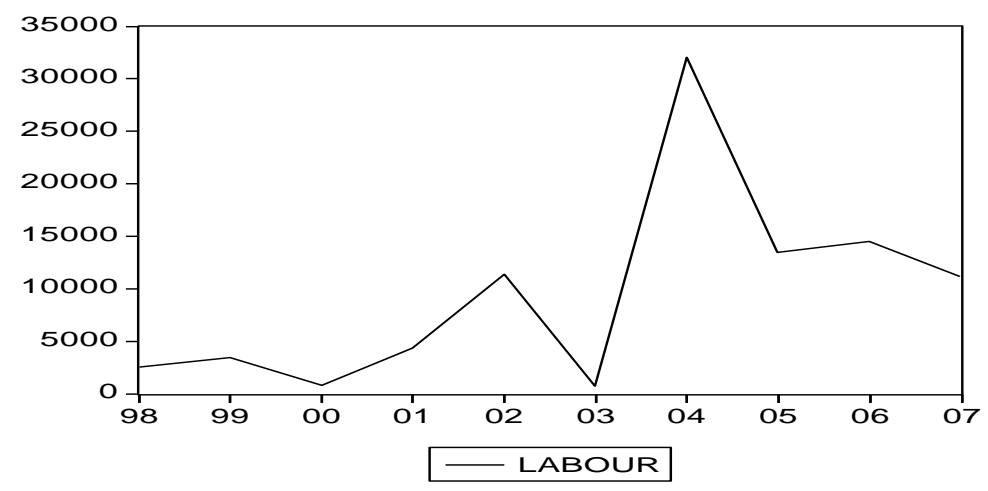

Gambar 23. Tenaga kerja yang terserap melalui metode grafik

Setelah kesemua data di uji apakah stationer atau tidak stationer maka dapat di ketahui bahwa semua data yaitu PDRB, pengeluaran pemerintah, investasi, maupun tenaga kerja yang terserap tidak stationer. Maka untuk itu data akan di stationer melalui correlogram dengan difference tingkat 1, tetapi apabila tidak stationer pada difference tingkat 1 maka akan di difference tingkat 2.

Data produk domestik ratio bruto (PDRB) di stationerkan dengan difference tingkat 1 , sehingga :

\section{Tabel 24. PDRB (produk domestik ratio bruto)}

Date: 01/08/09 Time: 02:39

Sample: 19982007

Included observations: 9

\begin{tabular}{|c|c|c|c|c|c|}
\hline Autocorrelation & Partial Correlation & $A C$ & PAC & Q-Stat & Prob \\
\hline$\left.\right|^{* *}$ & & 10.548 & 0.548 & 3.7224 & 0.054 \\
\hline $\mid$ & & 0.049 & -0.361 & 3.7558 & 0.153 \\
\hline$* * \mid$ & ${ }^{\prime}$ & $3-0.217$ & -0.092 & 4.5360 & 0.209 \\
\hline ***| & **| & $4-0.423$ & -0.337 & 8.0788 & 0.089 \\
\hline$* * \mid$ & $\left.\right|^{* *}$ & $5-0.270$ & 0.208 & 9.8809 & 0.079 \\
\hline *1 & 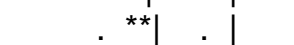 & $6-0.118$ & -0.263 & 10.341 & 0.111 \\
\hline * & & $7-0.061$ & 0.011 & 10.528 & 0.161 \\
\hline
\end{tabular}

Dalam table 24 tersebut terlihat pada autocorrelation bahwa gambar garis (bintang) tidak ada yang keluar melewati batas, sehingga dapat di katakan data stationer pada difference tingkat 1.

Data Pengeluaran pemerintah di stationerkan dengan difference tingkat 1, sehingga :

\section{Tabel 25. Pengeluaran Pemerintah}

Date: 01/08/09 Time: 02:39

Sample: 19982007

Included observations: 9

\begin{tabular}{|c|c|c|c|c|c|}
\hline Autocorrelation & Partial Correlation & $A C$ & PAC & Q-Stat & Prob \\
\hline * & *1 & $1-0.165$ & -0.165 & 0.3354 & 0.562 \\
\hline & & $2-0.126$ & -0.157 & 0.5602 & 0.756 \\
\hline & & $\begin{array}{ll}3 & 0.137\end{array}$ & 0.091 & 0.8679 & 0.833 \\
\hline & | & $4-0.039$ & -0.019 & 0.8980 & 0.925 \\
\hline * & *1 & $5-0.184$ & -0.174 & 1.7403 & 0.884 \\
\hline $1^{*}$ & 1 & $\begin{array}{ll}6 & 0.079\end{array}$ & -0.002 & 1.9487 & 0.924 \\
\hline
\end{tabular}


Dalam table 25 tersebut terlihat pada autocorrelation bahwa gambar garis (bintang) tidak ada yang keluar melewati batas, sehingga dapat di katakan data stationer pada difference tingkat 1.

Data investasi di stationerkan dengan difference tingkat 1, sehingga akan menghasilkan sebagai berikut :

\section{Tabel 26. Investasi}

\begin{tabular}{|c|c|c|c|c|c|}
\hline \multicolumn{6}{|c|}{$\begin{array}{l}\text { Date: 01/08/09 Time: 02:40 } \\
\text { Sample: } 19982007 \\
\text { Included observations: } 9\end{array}$} \\
\hline Autocorrelation & Partial Correlation & $\mathrm{AC}$ & PAC & Q-Stat & Prob \\
\hline$\left.\right|^{* *}$ & $.\left.\right|^{* *} \cdot \mid$ & $\begin{array}{ll}1 & 0.234\end{array}$ & 0.234 & 0.6777 & 0.410 \\
\hline$\left.\right|^{*}$ & & $\begin{array}{ll}2 & 0.129\end{array}$ & 0.078 & 0.9120 & 0.634 \\
\hline *| & ${ }^{*}$ & $3-0.096$ & -0.151 & 1.0638 & 0.786 \\
\hline${ }^{*} \mid$ & i & $4-0.094$ & -0.056 & 1.2396 & 0.872 \\
\hline$* * \mid$ & $*$ & $5-0.205$ & -0.155 & 2.2752 & 0.810 \\
\hline${ }^{*}$ & ${ }^{*}$ & $6-0.178$ & -0.110 & 3.3162 & 0.768 \\
\hline *1 &.$^{*}$ & $7-0.146$ & -0.072 & 4.3655 & 0.737 \\
\hline
\end{tabular}

Dalam table 26 tersebut terlihat pada autocorrelation bahwa gambar garis (bintang) tidak ada yang keluar melewati batas, sehingga dapat di katakan data stationer pada difference tingkat 1.

Data tenaga kerja yang terserap di stationerkan dengan difference tingkat 1 , sehingga akan menghasilkan sebagai berikut :

\section{Tabel 27. Tenaga kerja yang terserap}

\section{Date: 01/08/09 Time: 02:43}

Sample: 19982007

Included observations: 10

\begin{tabular}{|c|c|c|c|c|c|}
\hline Autocorrelation & Partial Correlation & $A C$ & PAC & Q-Stat & Prob \\
\hline & & 10.041 & 0.041 & 0.0226 & 0.880 \\
\hline & & 20.302 & 0.300 & 1.3873 & 0.500 \\
\hline & & $3-0.016$ & -0.041 & 1.3919 & 0.707 \\
\hline **| & ***| & $4-0.222$ & -0.343 & 2.3803 & 0.666 \\
\hline *l & $*$ & $5-0.162$ & -0.158 & 3.0077 & 0.699 \\
\hline ** & $*$ & $6-0.284$ & -0.115 & 5.4249 & 0.491 \\
\hline & & $7-0.089$ & 0.019 & 5.7415 & 0.570 \\
\hline & & $8-0.055$ & 0.023 & 5.9238 & 0.656 \\
\hline
\end{tabular}

Dalam table 27 tersebut terlihat pada autocorrelation bahwa gambar garis (bintang) tidak ada yang keluar melewati batas, sehingga dapat di katakan data stationer pada difference tingkat 1.

Setelah ke semua data yaitu PDRB, pengeluaran pemerintah, investasi, maupun tenaga kerja yang terserap menjadi stationer pada difference tingkat pertama, maka data langsung dapat di analisis.

\section{Regresi berganda (multiple regression)}


Adapun rumus Regresi berganda (multiple regression) untuk menganalisis pengaruh pengeluaran pemerintah, investasi, serta tenaga kerja yang terserap terhadap produk domestik ratio bruto (PDRB) di kota Samarinda adalah sebagai berikut :

$\mathrm{Y}_{\mathrm{t}}=\beta_{0}+\beta_{1} X_{1 t}+\beta_{2} \mathrm{X}_{2 \mathrm{t}}+\beta_{3} \mathrm{X}_{3 \mathrm{t}}+\beta_{4} \mathrm{X}_{4 \mathrm{t}}+\mathrm{e}_{\mathrm{t}} \quad$ (model stocastic)

Di mana

$$
\begin{array}{ll}
\mathrm{Y}_{\mathrm{t}} & : \text { PDRB } \\
\mathrm{X}_{1 \mathrm{t}} & : \text { Pengeluaran pemerintah } \\
\mathrm{X}_{2 \mathrm{t}} & : \text { Investasi } \\
\mathrm{X}_{3 \mathrm{t}} & : \text { Tenaga kerja yang terserap }
\end{array}
$$

TABEL 28. DATA PRODUK DOMESTIK RATIO BRUTO (PDRB), PENGELUARAN PEMERINTAH, INVESTASI, SERTA TENAGA KERJA YANG TERSERAP DI KOTA SAMARINDA

\begin{tabular}{|c|r|r|r|c|}
\hline TAHUN & PDRB & $\begin{array}{c}\text { PENGELUARAN } \\
\text { PEMERINTAH }\end{array}$ & INVESTASI & $\begin{array}{c}\text { TENAGA } \\
\text { KERJA YANG } \\
\text { TERSERAP }\end{array}$ \\
\hline 1998 & 4.192 .029 & 337.446 & 1.591 .535 & 14.972 \\
1999 & 5.405 .587 & 378.978 & 1.772 .582 & 13.318 \\
2000 & 6.077 .497 & 434.045 & 2.021 .605 & 13.560 \\
2001 & 6.993 .663 & 624.778 & 2.321 .694 & 21.855 \\
2002 & 8.414 .777 & 599.960 & 2.633 .330 & 19.180 \\
2003 & 9.852 .073 & 1.020 .043 & 4.113 .345 & 18.134 \\
2004 & 11.558 .177 & 1.272 .229 & 4.915 .447 & 17.726 \\
2005 & 13.125 .820 & 1.367 .734 & 5.752 .210 & 21.726 \\
2006 & 14.500 .247 & 1.529 .206 & 6.492 .986 & 18.363 \\
2007 & 15.868 .881 & 1.836 .514 & 7.642 .212 & 19.261 \\
\hline
\end{tabular}

Dengan menggunakan salah satu program (software) statistic yaitu

\begin{tabular}{|c|c|c|c|c|}
\hline \multicolumn{5}{|c|}{$\begin{array}{l}\text { Dependent Variable: D(PDRB) } \\
\text { Method: Least Squares } \\
\text { Date: 01/08/09 Time: 02:44 } \\
\text { Sample(adjusted): } 19992007 \\
\text { Included observations: } 9 \text { after adjusting endpoints } \\
\end{array}$} \\
\hline Variable & Coefficient| & Std. Error & t-Statistic & Prob. \\
\hline $\begin{array}{c}\text { C } \\
\text { D(PENGELUARAN) } \\
\text { D(INVESTASI) } \\
\text { LABOUR }\end{array}$ & $\begin{array}{r}849403.3 \\
-1.349916 \\
0.703698 \\
19.55760\end{array}$ & $\begin{array}{l}127145.9 \\
0.901335 \\
0.287705 \\
6.772878\end{array}$ & $\begin{array}{r}6.680539 \\
-1.497684 \\
2.445903 \\
2.887635 \\
\end{array}$ & $\begin{array}{l}0.0011 \\
0.1945 \\
0.0582 \\
0.0343\end{array}$ \\
\hline $\begin{array}{l}\text { R-squared } \\
\text { Adjusted R-squared } \\
\text { S.E. of regression } \\
\text { Sum squared resid } \\
\text { Log likelihood } \\
\text { Durbin-Watson stat }\end{array}$ & $\begin{array}{r}0.795482 \\
0.672771 \\
184206.6 \\
1.70 \mathrm{E}+11 \\
-119.2397 \\
2.304162\end{array}$ & $\begin{array}{l}\text { Mean depende } \\
\text { S.D. depender } \\
\text { Akaike info crit } \\
\text { Schwarz criter } \\
\text { F-statistic } \\
\text { Prob(F-statistic }\end{array}$ & & $\begin{array}{l}1297428 . \\
322017.1 \\
27.38661 \\
27.47426 \\
6.482561 \\
0.035598\end{array}$ \\
\hline \multicolumn{5}{|c|}{$\mathrm{Y}_{\mathrm{t}}=\beta_{0}+\beta_{1} X_{1 t}+\beta_{2} \mathrm{X}_{2 \mathrm{t}}+\beta_{3} \mathrm{X}_{3 \mathrm{t}}+\mathrm{e}_{\mathrm{t}}$} \\
\hline
\end{tabular}
Eviews maka data pada table 28 dapat di regresikan sebagai berikut:

Tabel 29. Hasil Regresi berganda (multiple regression) dengan program Eviews 
$\mathrm{D}\left(\mathrm{Y}_{\mathrm{t}}\right)$ : Difference tingkat pertama PDRB

$\mathrm{D}\left(\mathrm{X}_{1 \mathrm{t}}\right)$ : Difference tingkat pertama Pengeluaran pemerintah

$\mathrm{D}\left(\mathrm{X}_{2 \mathrm{t}}\right)$ : Difference tingkat pertama Investasi

$X_{3 t}$ : Tenaga Kerja yang terserap

Persamaan regresi ini menghasilkan intersep sebesar 849403,3. besarnya slope - 1,34 untuk pengeluaran pemerintah, $+0,70$ untuk investasi, +19,5 untuk tenaga kerja yang terserap. Yang mempunyai asumsi jika pengeluaran pemerintah naik atau bertambah satu juta rupiah maka di asumsikan produk domestik ratio bruto (PDRB) akan berkurang sebesar 1,34 juta. Selanjutnya jika investasi bertambah satu juta rupiah maka di asumsikan produk domestik ratio bruto (PDRB) akan bertambah sebesar satu juta. Selanjutnya jika tenaga kerja yang terserap bertambah satu juta orang maka di perkirakan produk domestik ratio bruto (PDRB) akan bertambah sebesar satu juta rupiah.

Koefisien Korelasi (R) dan Koefisien Determinasi $\left(R^{2}\right)$

Setelah mengetahui nilai koefisien $b_{0}, b_{1}$ dan $b_{2}$ persamaan garis regresinya maka untuk mengukur keeratan hubungan antara variabel $X_{1}$ dan $X_{2}$ serta $X_{3}$ terhadap variabel $Y$ dapat di lakukan dengan cara menghitung koefisien korelasinya (Multiple Coefficient of Correlation) dapat di lihat pada tabel 30 berikut :

Tabel 30. Hasil Regresi berganda (multiple regression)

Dependent Variable: D(PDRB)

Method: Least Squares

Date: 01/08/09 Time: 02:44

Sample(adjusted): 19992007

Included observations: 9 after adjusting endpoints

\begin{tabular}{|c|c|c|c|c|}
\hline Variable & Coefficient & Std. Error & $\mathrm{t}-$ Statistic & Prob \\
\hline $\begin{array}{r}\mathrm{C} \\
\text { D(PENGEL } \\
\text { D(INVES } \\
\text { LABO } \\
\end{array}$ & & & & \\
\hline $\begin{array}{l}\text { Adjusted R-squared } \\
\text { S.E. of regression } \\
\text { Sum squared resid } \\
\text { Log likelihood } \\
\text { Durbin-Watson stat }\end{array}$ & $\begin{array}{r}0.795482 \\
0.672771 \\
184206.6 \\
1.70 \mathrm{E}+11 \\
-119.2397 \\
2.304162\end{array}$ & \multicolumn{2}{|c|}{$\begin{array}{l}\text { Mean dependent var } \\
\text { S.D. dependent var } \\
\text { Akaike info criterion } \\
\text { Schwarz criterion } \\
\text { F-statistic } \\
\text { Prob(F-statistic) }\end{array}$} & $\begin{array}{l}1297428 . \\
322017.1 \\
27.38661 \\
27.47426 \\
6.482561 \\
0.035598\end{array}$ \\
\hline
\end{tabular}

Berdasarkan tabel 31, di peroleh koefisien korelasi sebesar $\mathbf{R}=\mathbf{0 . 8 9}$ angka ini menunjukkan pengaruh yang sangat erat dari variabel pengeluaran pemerintah, investasi serta tenaga kerja yang terserap.

Untuk mengukur derajat kecocokan / ketepatan (Goodness of Fit) variabel $X_{1}, X_{2}$, serta $X_{3}$ terhadap Variabel $Y$ di dapat $R^{2}(R$ square) $=0,79$ artinya perubahan variabel pengeluaran pemerintah, investasi, serta tenaga kerja yang terserap dapat menjelaskan 
variabel produk domestik ratio bruto (PDRB) sebesar $79,5 \%$, sedangkan sisanya $(\mathbf{1 0 0}-\mathbf{7 9 , 5}=\mathbf{2 0 , 5} \%)$ di jelaskan oleh faktorfaktor lain.

Uji t ( Uji parsial / secara terpisah)

Pengujian hipotesis di lakukan terhadap $\beta$ (beta), dimana garis regresi $\beta$ di taksir $b$ dalam hal ini digunakan uji t untuk menguji koefisien $\mathbf{b}_{1}, \mathbf{b}_{2}, \mathbf{b}_{3}$ terhadap $Y$ dengan tingkat kepercayaan (level of confident) $\mathbf{5} \%$, serta $\mathbf{1 0} \%$. Dapat di lihat pada tabel 30 berikut ini :

Tabel 31. Hasil Perhitungan Uji t dengan Program EVIEWS

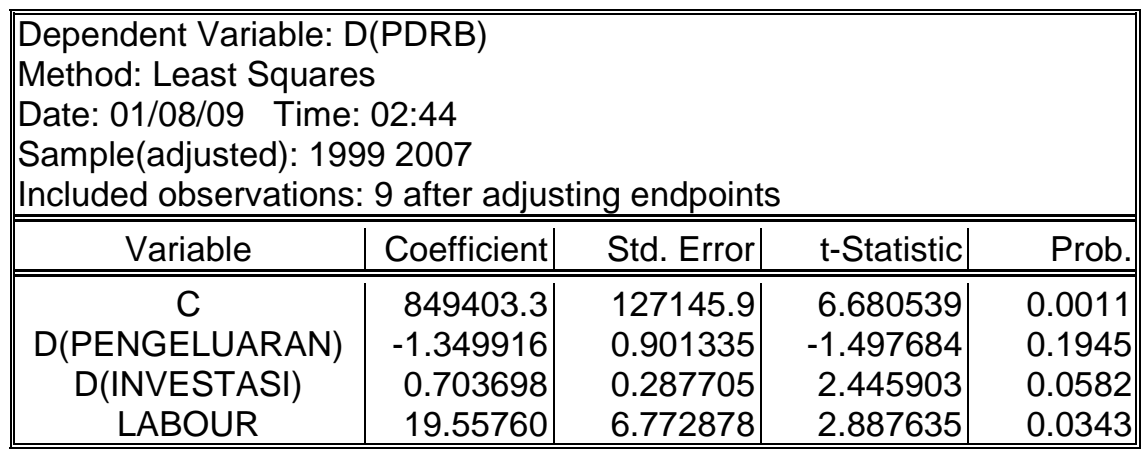

Di mana :

a. Koefisien untuk Pengeluaran pemerintah $\left(b_{1}\right)$

Dari hasil perhitungan diperoleh nilai $t_{\text {hitung }}=-1,49$ sedangkan $t_{\text {tabel atau kritis }}=2,44(5 \%), 1,94(10 \%)$ (nilai $t$ kritis atau tabel di peroleh dari $t$ tabel yakni sebesar 2,44 serta 1,94 dengan $\alpha=5 \%$ dan df (degree of freedom) $(n-k)=10-4$ sebesar 6$)$.

Jadi berdasarkan perhitungan tersebut nilai $\mathbf{t}$ hitung $<$ nilai $\mathbf{t}$ kritis $(-1,49<2,44)(-1,49<1,94)$ maka Ho di terima atau menolak $\mathrm{Ha}$, artinya pengeluaran pemerintah tidak mempunyai pengaruh yang signifikan terhadap produk domestik ratio bruto (PDRB) di kota Samarinda.

b. Koefisien untuk Investasi $\left(b_{2}\right)$

Dari hasil perhitungan diperoleh nilai $t_{\text {hitung }}=2,445$ sedangkan $t_{\text {tabel }}=2,446(5 \%), 1,943(10 \%)$.

Jadi berdasarkan perhitungan tersebut nilai $t$ hitung $<$ nilai $t$ kritis $(2,445<2,446)$ maka Ho di terima atau menolak Ha tetapi pada level of confident $10 \% t$ hitung $>$ nilai $t$ kritis $(2,445>1,943)$ maka Ho di tolak atau menerima $\mathrm{Ha}$ bahwa, artinya investasi tidak mempunyai pengaruh yang signifikan terhadap produk domestik ratio bruto (PDRB) di kota Samarinda (pada level $5 \%$ ) tetapi investasi 
juga mempunyai pengaruh yang signifikan terhadap produk domestik ratio bruto (PDRB) di kota Samarinda (pada level $10 \%$ ).

c. Koefisien untuk Tenaga kerja yang terserap $\left(b_{3}\right)$

Dari hasil perhitungan diperoleh nilai $t_{\text {hitung }}=\mathbf{2 , 8 8}$ sedangkan $t_{\text {tabel }}=2,44(5 \%), 1,94(10 \%)$.

Jadi berdasarkan perhitungan tersebut nilai $\mathbf{t}$ hitung $>$ nilai $\mathbf{t}$

kritis $(2,88>2,44)(2,88>1,94)$ maka Ho (hipotesis nul) di tolak atau menerima $\mathrm{Ha}$ (hipotesis alternative), artinya Tenaga kerja yang terserap memberikan pengaruh signifikan terhadap produk domestik ratio bruto (PDRB) kota Samarinda.

Kesimpulan

Sehingga dari ketiga koefisien regresi yaitu pengeluaran pemerintah, investasi serta tenaga kerja yang terserap dapat di simpulkan bahwa Tenaga kerja yang terserap memberikan pengaruh signifikan daripada pengeluaran pemerintah serta investasi terhadap produk domestik ratio bruto (PDRB) kota Samarinda.

Uji F (Uji simultan / secara bersama-sama)

Pengujian koefisien regresi secara bersama-sama (uji simultan) di gunakan pengujian hipotesis uji $\mathrm{F}$ atau Fisher Test pada tingkat kepercayaan $95 \%$ atau $\alpha=0,05$. Dapat di lihat pada tabel 33 berikut

Tabel 32. Hasil Perhitungan Uji F

\begin{tabular}{|c|c|c|c|}
\hline R-squared & 0.795482 & Mean dependent & 1297428. \\
\hline Adjusted R-squared & 0.672771 & $\begin{array}{l}\text { S.D. dependent } \\
\text { var }\end{array}$ & 322017.1 \\
\hline S.E. of regression & 184206.6 & $\begin{array}{l}\text { Akaike info } \\
\text { criterion }\end{array}$ & 27.38661 \\
\hline Sum squared resid & $1.70 \mathrm{E}+11$ & $\begin{array}{l}\text { Schwarz } \\
\text { criterion }\end{array}$ & 27.47426 \\
\hline Log likelihood & -119.2397 & F-statistic & 6.482561 \\
\hline Durbin-Watson stat & 2.304162 & Prob(F-statistic) & 0.035598 \\
\hline
\end{tabular}

Berdasarkan tabel 33 di dapat nilai $\mathbf{F}_{\text {hitung }}=6,482$ (dalam tabel ANOVA ${ }^{b}$ ) sedangkan nilai $F_{\text {tabel }}$ dengan $\alpha=0,05$ adalah $F_{\text {tabel }}$ $((k-1)(n-k))=4,75$. Jadi dari perhitungan diatas dapat di lihat bahwa $F_{h}=6,482>F_{t}=4,75$ atau signifikan $F<5 \%$ yang berarti bahwa pengeluaran pemerintah, investasi, serta tenaga kerja yang terserap secara bersama-sama berpengaruh signifikan terhadap produk domestik ratio bruto (PDRB). Ho ditolak dan $\mathrm{H}_{\mathrm{a}}$ diterima. 


\section{Uji asumsi klasik}

\section{MULTIKOLINEARITAS}

Untuk mendeteksi Multikolinearitas dapat di lihat dari :

a. Nilai $R^{2}$ tinggi tetapi hanya sedikit variabel independen yang signifikan.

b. Korelasi parsial antar variabel independen.

c. Dapat di lihat dari nilai VIF untuk masing-masing prediktor. Dengan syarat nilai VIF tidak melebihi nilai 10. (SPSS)

Tabel 33. Mendeteksi Multikolinearitas melalui korelasi parsial antar Independen (Correlation Matrix)

\begin{tabular}{|c|c|c|c|c|}
\hline & $\begin{array}{c}\text { PDRB } \\
(\mathbf{Y})\end{array}$ & $\begin{array}{c}\text { PENGELUARAN } \\
(\mathbf{X} 1)\end{array}$ & $\begin{array}{c}\text { INVESTASI } \\
(\mathbf{X} 2)\end{array}$ & $\begin{array}{c}\text { ANGKATAN_KERJA } \\
(\mathbf{X 3})\end{array}$ \\
\hline \hline PDRB & 1.000000 & 0.987281 & 0.988910 & 0.563573 \\
PENGELUARAN & 0.987281 & 1.000000 & 0.995841 & 0.561045 \\
INVESTASI & 0.988910 & 0.995841 & 1.000000 & 0.526966 \\
$\begin{array}{c}\text { ANGKATAN_KE } \\
\text { RJA }\end{array}$ & 0.563573 & 0.561045 & 0.526966 & 1.000000 \\
\hline
\end{tabular}

Bila di lihat pada tabel 32 maka dapat di simpulkan terdapat gejala multikolinearitas, karena tingginya nilai koefisien korelasi. Seperti korelasi $Y$ dengan $X_{1}$ sebesar 0,98 , korelasi $Y$ dengan $X_{2}$.

\section{Penyembuhan (Treatment)}

1. Tanpa ada perbaikan

2. Dengan Perbaikan melalui :

- Menghilangkan variabel independen

- Transformasi variabel

- Penambahan data

Solusinya untuk menghilangkan masalah multikolinearitas ini melalui transformasi variabel. Sehingga menjadi :

\section{Tabel 34. Transformasi Variabel (first difference) (Correlation Matrix)}

\begin{tabular}{|c|c|c|c|c|}
\hline & $\begin{array}{c}\text { D(PDRB) } \\
(\mathbf{Y})\end{array}$ & $\begin{array}{c}\text { D(PENGELUARAN) } \\
(\mathbf{X} 1)\end{array}$ & $\begin{array}{c}\text { D(INVESTASI) } \\
(\mathbf{X 2})\end{array}$ & $\begin{array}{c}\text { D(Tenaga_kerja) } \\
(\mathbf{X} 3)\end{array}$ \\
\hline \hline D(PDRB) & 1.000000 & 0.295432 & 0.563682 & 0.203843 \\
D(PENGELUARAN) & 0.295432 & 1.000000 & 0.859423 & -0.015190 \\
D(INVESTASI) & 0.563682 & 0.859423 & 1.000000 & -0.248112 \\
D(ANGKATAN_KERJA) & 0.203843 & -0.015190 & -0.248112 & 1.000000 \\
\hline
\end{tabular}

Korelasi parsial $\mathrm{Y}$ dengan $\mathrm{X} 1$ adalah 0,29 , korelasi parsial $\mathrm{Y}$ dengan $\mathrm{X} 2$ adalah 0,56 , korelasi parsial $\mathrm{X} 1$ dengan $\mathrm{X} 3$ adalah $-0,01$. korelasi 
parsial $\mathrm{Y}$ dengan $\mathrm{X} 3$ adalah 0,20. dengan rendahnya koefisien korelasi maka di duga tidak terdapat masalah multikolinearitas.

\section{HETEROSKEDASTISITAS}

Bahwasanya heteroskedastisitas akan sering di temukan dalam data cross section. Sementara dalam penelitian ini, data yang di gunakan adalah time series, kemungkinan jarang mengandung unsur heteroskedastisitas.

\section{AUTOKORELASI}

Untuk mendeteksi Autokorelasi dapat di lihat dari :

\section{Tabel 35. Uji Durbin-Watson}

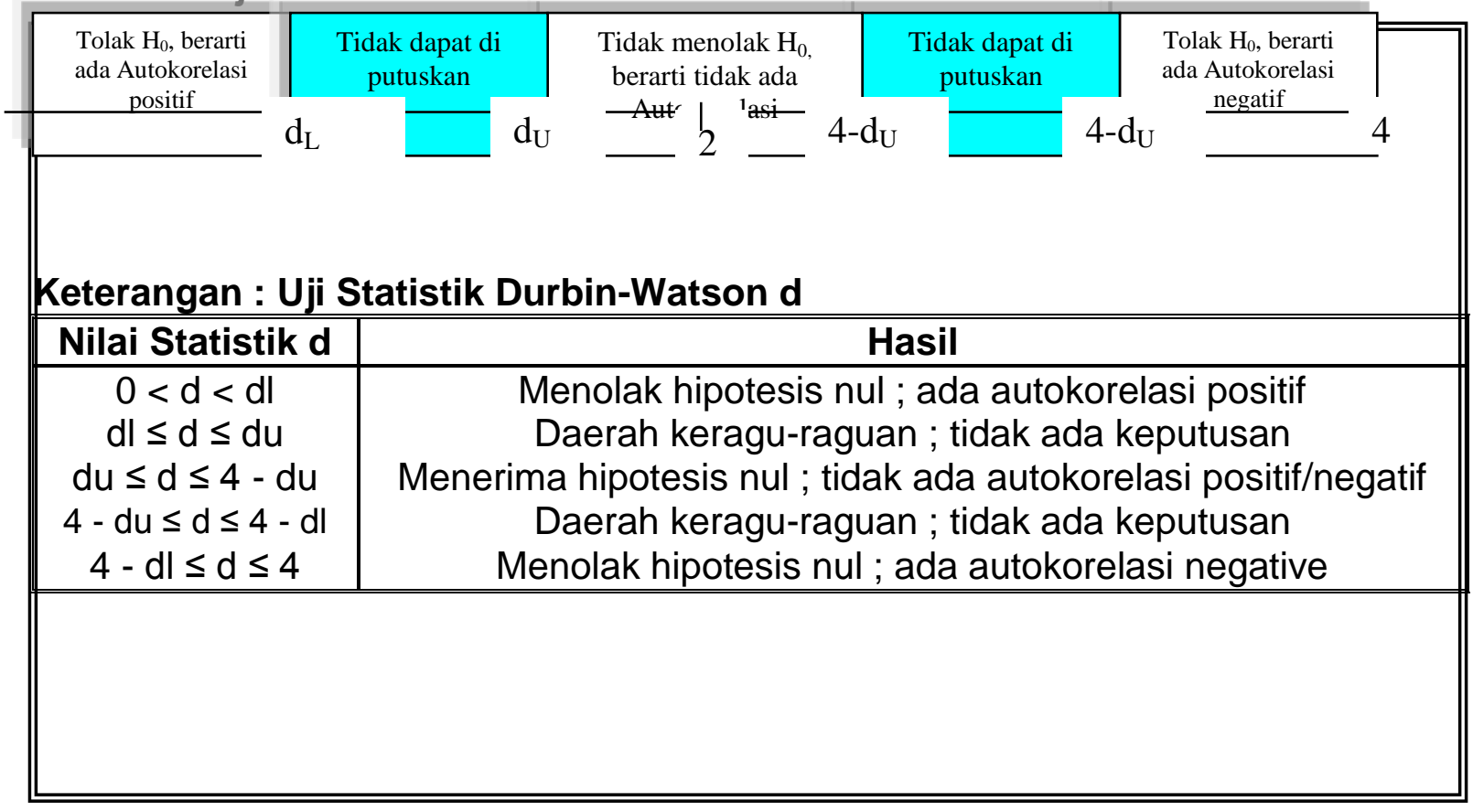

Tabel. 36 Hasil Perhitungan Durbin Watson

\begin{tabular}{|c|c|c|c|}
\hline R-squared & 0.795482 & $\begin{array}{c}\text { Mean dependent } \\
\text { var }\end{array}$ & 1297428. \\
\hline Adjusted R-squared & 0.672771 & $\begin{array}{c}\text { S.D. dependent } \\
\text { var }\end{array}$ & 322017.1 \\
\hline S.E. of regression & 184206.6 & $\begin{array}{l}\text { Akaike info } \\
\text { criterion }\end{array}$ & 27.38661 \\
\hline Sum squared resid & $1.70 \mathrm{E}+11$ & $\begin{array}{l}\text { Schwarz } \\
\text { criterion }\end{array}$ & 27.47426 \\
\hline Log likelihood & -119.2397 & F-statistic & 6.482561 \\
\hline Durbin-Watson stat & 2.304162 & Prob(F-statistic) & 0.035598 \\
\hline
\end{tabular}

Nilai statistik hitung Durbin-Watson $=2,304162$ sedangkan nilai kritis $d$ dengan $\alpha=5 \%$ dengan $n=10$ dan $k=3$ untuk $d_{L}=0,525$ dan nilai $d_{u}=2,016$. sedangkan nilai $4-d_{L}(4-0,525=3,475)$ dan $4-d_{u}$ 
$(4-2,016=1,984)$ maka dapat di simpulkan tidak ada masalah autokorelasi.

\section{B. Pembahasan}

Penelitian ini mencoba melihat pengaruh dari sisi Pengeluaran pemerintah $\left(X_{1}\right)$, Investasi $\left(X_{2}\right)$ serta Tenaga kerja yang terserap $\left(X_{3}\right)$ terhadap produk domestik ratio bruto (PDRB) (Y) di Kota Samarinda.

Hasil perhitungan koefisien korelasi di peroleh nilai 0,89 yang menunjukkan bahwa terdapat hubungan yang erat antara variabel Pengeluaran pemerintah $\left(X_{1}\right)$, Investasi $\left(X_{2}\right)$ serta Tenaga kerja yang terserap $\left(X_{3}\right)$ terhadap produk domestik ratio bruto (PDRB).

Hasil perhitungan koefisien determinasi $\left(\mathbf{R}^{2}\right)$ dengan nilai $\mathbf{0 , 7 9 5}$ yang menunjukkan kemampuan antara variabel Pengeluaran pemerintah $\left(X_{1}\right)$, Investasi $\left(X_{2}\right)$ serta Tenaga kerja yang terserap $\left(X_{3}\right)$ dalam menjelaskan produk domestik ratio bruto (PDRB) (Y). Yang artinya bahwa $79,5 \%$ persen untuk variabel Pengeluaran pemerintah, Investasi serta Tenaga kerja yang terserap ternyata mempunyai pengaruh yang erat terhadap produk domestik ratio bruto (PDRB) di kota Samarinda, hal ini bisa di analogikan bahwa semakin bagus PDRB suatu daerah maka bisa di katakan tingkat perekonomiannya mengalami kemajuan atau kemakmuran, sehingga kemampuan fiskalnya akan meningkat. Tentunya di dukung dengan SDA (human resources) yang handal, banyak faktor-faktor yang mampu menciptakan SDA yang handal, salah satunya skill dan upah. Untuk membiayai upah dan mengupgrade skill sumber daya manusia (SDM) maka dapat menggunakan belanja rutin dengan menggunakan dana alokasi umum (DAU) yang itu termasuk dalam komponen pengeluaran pemerintah.

Pengeluaran pemerintah yang di keluarkan untuk proyekproyek pembangunan di harapkan ke depannya dapat meningkatkan kesejahteraan masyarakat. Tentunya dengan di dukung good governance sehingga tidak terjadi kebocoran atau dengan istilah korupsi, kolusi, nepotisme (KKN). Tetapi bukan proyek-proyek mercusuar yang menggunakan dana sangat besar kemudian setelah di realisasikan tidak ada pemeliharaan (maintenance), sebagai contoh : pembangunan stadion utama Palaran, pada kenyataannya setelah selesai kegiatan pekan olah raga nasional (PON) tidak lagi di lakukan kegiatan pembangunan kelanjutan, dengan alasan pihak swasta belum memberikan sepenuhnya kepada pihak pemerintah. Seharusnya pihak pemerintah dan pihak swasta dalam melaksanakan proyek-proyek pembangunan perlu melakukan koordinasi yang baik (simbiolis mutualisme).

Kalau di lihat banyak proyek-proyek pemerintah seperti sia-sia saja di laksanakan (useless). Kebanyakan berpendapat bahwa 


\section{pemerintah kota Samarinda terlihat terburu-buru, tidak melihat pengaruhnya kedepannya 10 hingga 25 tahun mendatang. Semuanya hanya memandang uang (money is everything), semoga untuk ke depannya mental para pejabatnya adalah bermental TAKWA (takut kepada ALLAH SWT).}

Investasi mempunyai peran penting dalam perekonomian suatu negara tidak terkecuali kota Samarinda. Alasannya yaitu pertama, investasi mampu menciptakan pendapatan dan kedua investasi dapat memperbesar kapasitas produksi perekonomian dengan cara meningkatkan stock modal. Pendapat ini sejalan dengan yang di kemukakan oleh Harrod Domar bahwa investasi tidak hanya mempengaruhi permintaan melalui multiplier effect, tetapi juga mempengaruhi penawaran melalui pengaruhnya terhadap peningkatan kapasitas produksi. Artinya semakin besar investasi yang di tanamkan maka akan mempengaruhi kelangsungan (durability) akan suatu produksi dalam hal ini adalah proyek-proyek pembangunan sehingga secara tidak langsung akan memperbesar kapasitas produksi seperti sebagai contoh pemeliharaan, teknologi, dan lain-lain.

Dalam penelitian ini investasi tidak terlalu memberikan pengaruh yang signifikan terhadap produk domestik ratio bruto (PDRB). Banyak faktor-faktor yang mempengaruhinya seperti faktor keamanan (baik dari bencana alam atau di akibatkan faktor manusia), ketertiban hukum, dan lain-lain (Wikipedia : 2007). Sebagai contoh ancaman bom, maupun kondisi geografis suatu daerah. Faktor lain adalah faktor dari diri manusia tersebut seperti malas, sibuk, dan lain-lain. Sebagi contoh : (Tribun Kaltim, Minggu 07-04-2008) di katakan bahwa ada pertemuan dengan para pihak investor dengan pihak pemerintah di Lipan Hill membahas masalah penanaman investasi di kota Samarinda, alhasil ternyata dari pihak pemerintah tidak ada yang datang, dengan alasan adanya kesibukan di luar kota. Ini mengindikasikan kurangnya perhatian pemerintah terhadap masalah ini. Untuk itu di perlukan win-win solution untuk mengatasinya, jangan ketika akan adanya pemilihan pejabat pemerintah baru serius melaksanakan (janji-janji pembohong).

Jenis faktor produksi secara teoritis di bagi menjadi empat, yaitu : lahan, tenaga kerja, modal dan manajemen.. faktor produksi lahan dan tenaga kerja sering di sebut dengan input utama (mother is input). Sedangkan modal dan manajemen adalah hasil modifikasi dari input utama dan sering di katakan sebagai input kedua (father is input).

Faktor produksi tenaga kerja (labor) merupakan faktor produksi yang penting untuk di perhatikan dalam proses produksi dalam jumlah yang cukup bukan saja di lihat dari tersedianya tenaga keja tetapi juga kualitas dan macam tenaga kerja. Semakin baik sumber daya manusia (SDM) maka akan semakin efisien dan efektif dalam melaksanakan produksi.

Sehingga dalam penelitian ini di katakan bahwa tenaga kerja yang terserap memberikan pengaruh yang signifikan terhadap produk domestik 
ratio bruto (PDRB). Artinya tanpa ada orang yang bekerja atau manusianya maka suatu perekonomian tidak akan berjalan.

Pertanyaannya bagaimana menciptakan kesempatan kerja luas yang akan menambah tenaga kerja yang terserap sehingga mengurangi tingkat pengangguaran. Untuk itu perlu perhatian dari pemerintah terhadap masalah ini salah satunya melalui :

1. Menciptakan kesempatan kerja dengan cara membuka dunia usaha salah satunya melalui proyek-proyek pemerintah. Sehingga masyarakat turut berpartisipasi di dalam kegiatan tersebut.

2. Mengajak para investor baik pihak asing maupun pihak lokal dalam menginvestasikan dananya untuk menciptakan kesempatan kerja Sehingga apabila di laksanakan InsyaALLAH, akan mengurangi tingkat pengangguran di kota Samarinda. Tetapi sekalilagi untuk melakukan kesemuanya itu memerlukan dukungan dari semua pihak termasuk masyarakat itu sendiri artinya jangan di bebankan hanya kepada pemerintah saja serta mental dari manusia tersebut (IMTAK) iman serta takwa. Tiada gading yang tak retak " kesemuanya masih bisa di perbaiki".

Berdasarkan analisis dan pembahasan yang telah di kemukakan, maka hipotesis awal yang menyatakan bahwa :

1. Pengeluaran pemerintah memberikan pengaruh positif terhadap produk domestik ratio bruto (PDRB) kota Samarinda adalah tidak terbukti.

2. Investasi memberikan pengaruh positif terhadap produk domestik ratio bruto (PDRB) kota Samarinda adalah tidak terbukti.

3. Tenaga kerja yang terserap (labour force) memberikan pengaruh positif terhadap produk domestik ratio bruto (PDRB) kota Samarinda adalah terbukti .

4. Pengeluaran pemerintah, Investasi, serta Tenaga kerja yang terserap secara bersama-sama (Simultaneous) memberikan pengaruh positif terhadap produk domestik ratio bruto (PDRB) kota Samarinda adalah terbukti.

5. Diantara variabel-variabel yaitu pengeluaran pemerintah, investasi, serta tenaga kerja yang terserap, yang berpengaruh dominan adalah variabel investasi adalah tidak terbukti. 


\section{BAB V \\ KESIMPULAN DAN SARAN}

\section{A. Kesimpulan}

Dari hasil analisis dan pembahasan yang telah di kemukakan pada bab yang sebelumnya, maka dapat di kemukakan kesimpulan sebagai berikut :

1. Pada tahun 1998 jumlah pengeluaran pemerintah sebesar 337446 juta, tahun 1999 pengeluaran pemerintah 378978 juta, tahun 2000 pengeluaran pemerintah sebesar 434045 juta, tahun 2001 pengeluaran pemerintah adalah sebesar 624778 juta, tahun 2002 pengeluaran pemerintah sebesar 599960, tahun 2003 pengeluaran pemerintah naik sebesar 1020043 juta, tahun 2004 pengeluaran pemerintah adalah sebesar 1272229 juta, tahun 2005 pengeluaran pemerintah adalah sebesar 1367734 juta, tahun 2006 pengeluaran pemerintah adalah sebesar 1529206, tahun 2007 sebesar 1836514 juta. Tetapi setelah di lakukan pengujian ternyata pengeluaran pemerintah tidak memberikan pengaruh yang signifikan terhadap produk domestik ratio bruto (PDRB), bahwa nilai t hitung $<$ nilai $t$ kritis $(-1,49<2,44)(-1,49<1,94)$ pada tingkat kepercayaan $5 \%$ dan $10 \%$ atau nilai probabilitas 0,19 .

2. Investasi keseluruhan (Pemerintah dan Swasta) pada tahun 1998 adalah sebesar Rp. 1.591.535, tahun 1999 investasi sebesar Rp. 1.772.582, tahun 2000 investasi sebesar Rp. 2.021.605, tahun 2001 investasi sebesar Rp. 2.321.694, tahun 2002 Investasi sebesar Rp. 2.633.330, tahun 2003 investasi sebesar Rp. 4.113.345, tahun 2004 investasi sebesar Rp. 4.113.345, tahun 2005 investasi sebesar Rp. 5.752.210, tahun 2006 investasi sebesar Rp. 6.492.986, tahun 2007 investasi sebesar Rp. 7.642.212. Setelah di lakukan pengujian ternyata investasi tidak tidak mempunyai pengaruh yang signifikan terhadap produk domestik ratio bruto (PDRB) di kota Samarinda (pada level $5 \%$ ) nilai $\mathrm{t}$ hitung $<$ nilai $\mathrm{t}$ kritis $(2,445<2,446)$, Tetapi pada level of confident $10 \%$ t hitung > nilai t kritis $(2,445>1,943)$ maka Ho di tolak atau menerima $\mathrm{Ha}$ bahwa, artinya investasi mempunyai pengaruh yang signifikan terhadap produk domestik ratio bruto (PDRB) di kota Samarinda (pada level $10 \%$ ). Artinya semakin kuat 
investasi yang di tanamkan maka akan memberikan pengaruh terhadap produk domestik ratio bruto (PDRB) di kota Samarinda.

3. Pada tahun 1998 tenaga kerja yang terserap untuk kota Samarinda adalah sebanyak 14.972 orang. Kemudian pada tahun 1999 tenaga kerja yang terserap untuk kota Samarinda adalah sebesar 13.318 orang. Pada tahun 2000 tenaga kerja yang terserap untuk kota Samarinda adalah sebesar 13.560 orang. Pada tahun 2001 tenaga kerja yang terserap untuk kota Samarinda adalah sebesar 21.855 orang. Kemudian pada tahun 2002 tenaga kerja yang terserap untuk kota Samarinda adalah sebesar 19.180 orang. Pada tahun 2003 tenaga kerja yang terserap untuk kota Samarinda adalah sebesar 18.134 orang. pada tahun 2004 tenaga kerja yang terserap untuk kota Samarinda adalah sebesar 17.726 orang. pada tahun 2005 tenaga kerja yang terserap untuk kota Samarinda adalah sebesar 21.726 orang. pada tahun 2006 tenaga kerja yang terserap untuk kota Samarinda adalah sebesar 18.363 orang. kemudian pada tahun 2007 tenaga kerja yang terserap untuk kota Samarinda adalah sebesar 19.261 orang. Jadi berdasarkan perhitungan nilai t hitung $>$ nilai t kritis $(2,88>2,44)(2,88>1,94)$ pada tingkat keprcayaan $5 \%$ dan $10 \%$ artinya Tenaga kerja yang terserap memberikan pengaruh signifikan terhadap produk domestik ratio bruto (PDRB) kota Samarinda. Semakin baik kesempatan kerja yang tercipta maka akan memberikan pengaruh yang signifikan terhadap produk domestik ratio bruto (PDRB).

\section{B. Saran}

Setelah melakukan penelitian dan melakukan perhitungan dari data yang di kumpulkan, maka ada beberapa saran yang penulis ingin sampaikan :

1 Pemerintah harus mengolah sektor-sektor pada produk domestik ratio bruto (PDRB) dengan sangat bijaksana dan jujur serta mendistribusikan hasil dari pengelolaan sektor-sektor tersebut secara adil dan merata kepada masyarakat. Usaha dalam meningkatkan produk domestik ratio bruto (PDRB) akan menciptakan kesempatan kerja bagi masyarakat. Dengan demikian pendapatan masyarakat akan meningkat, sehingga masyarakat dapat memenuhi kebutuhan hidupnya lebih baik

2 Produk domestik ratio bruto (PDRB) sebagai salah satu indikator makro ekonomi yang penting untuk menggambarkan pertumbuhan ekonomi suatu wilayah. Maka sudah sewajarnya Produk domestik ratio bruto (PDRB) harus selalu di tingkatkan. Pemerintah dapat membuat kebijakan-kebijakan di berbagai sektor Produk domestik ratio bruto (PDRB), untuk memudahkan masyarakat untuk berwirausaha di sektor- sektor tersebut. Pemerintah dapat membuat kebijakan - kebijakan di berbagai sektor Produk domestik ratio bruto (PDRB), untuk memudahkan masyarakat untuk 
berwiraswasta di sektor-sektor tersebut. Pemberian kredit usaha secara berkala merupakan bantuan yang sangat berarti bagi masyarakat yang ingin berwira swasta.

\section{REFERENCES}

Abdul Halim, 2001, Manajemen Keuangan Daerah, Edisi I, UPP AMP YKPN, Yogyakarta.

Abdul Rachim AF, 2003, Menyiasati dan Memikul Keuangan Daerah Kota Samarinda, Cetakan 1, Airlangga University Press, Surabaya.

Ahmad Yani, , 2002, Hubungan Keuangan Antara Pemerintah Pusat dan Daerah di Indonesia, PT Raja Grafindo Persada, Jakarta..

Anonim, 2005, Samarinda Dalam Angka 2005, Badan Pusat Statistik Tingkat II Samarinda.

A. Widarjono,. (2005).Ekonometrika Teori dan Aplikasi untuk Ekonomi dan Bisnis. Yogyakarta : Ekonisia.

Atep Adya Barata dan Bambang Trihartanto, 2004, Kekuasaan Pengelolaan Keuangan Negara Daerah, Cetakan I, PT Elex Media Komputindo, Jakarta.

B. Machfud Sidik, Raksaka Mabi, Robert Simanjuntak, dan Bambang Brojdonegoro, 2002, Dana Alokasi Umuin Konsep,Hambatan dan Prospek Di Era Otonomi Daerah, Cetakan 1, PT Kompas Media Nusantara, Jakarta.

DJ. Mamesah,1995, Sistem Administrasi Keuangan Daerah, PT Gramedia Pustaka Utama, Jakarta.

Josef Riwo Kaho,1997, Prospek Otonomi Daerah di Negara Republik Indonesia, PT Raja Grafindo Persada, Jakarta.

J. Supranto, 1995, Ekonometrika, LP FE-UI, Jakarta.

Mardiasmo, 2002, Perpajakan, Edisi Resivi, Audi, Yogyakarta. 
Panglima Saragih, Juli, 2003, Desentralisasi Fiskal dan Keuangan Daerah Dalam Otonomi, Cetakan I, Ghalia Indonesia, Jakarta.

Suparmoko, 2002, Ekonomi publik Untuk Keuangan dan Pembangunan Daerah, Edisi 1, Audi, Yogyakarta. 